\title{
Identity Statuses among Kuwaitis
}

\author{
Ramadan A. Ahmed Ph.D. \\ Former Professor of Psychology \\ Kuwait University, Kuwait \\ Tel:20-10-1614-6272Ｅ-mail: ramadan-a-ahmed@hotmail.com
}

Maha J. A. Al-Jarallah Ph.D. (Corresponding author)

The Social Development Office

Ministry of Social Affairs, Kuwait

Tel: 96-56-077-7730Ｅ-mail: maha-aljarallah@hotmail.com

Received: Dec. 1, 2020

Accepted: Feb. 19, $2021 \quad$ Published: February 19, 2021

doi:10.5296/jse.v11i1.18219

URL: https://doi.org/10.5296/jse.v11i1.18219

\begin{abstract}
The present study investigated the identity statuses: Achievement, moratorium, foreclosure, and diffusion, and their ideological and relational aspects in samples of Kuwaiti adolescents, youth, and adults ( $\mathrm{N}=3621$ aged between 12 and 64 years; 1159 (or 32\%) males, and 2462 (or $68 \%$ ) females; and 2945 (or $81.3 \%$ ) aged 24 years and younger, and 676 (or 18.7\%) aged 25 years and older. By using an Arabic version of Bennion's and Adams' Extended Objective Measure of Ego Statuses - 2 (EOMES - 2). Results showed that a) 18.8\%, 16.0\%, 20.5\%, and $17.3 \%$ of Kuwaiti participants were classified as identity achieved, moratorium, foreclosed or diffused, respectively. B) Males, compared with their female counterparts, scored significantly higher on Achievement and Foreclosure, and their ideological and relational aspects. No significant differences have been found between the two sexes on Moratorium and Diffusion and their ideological and relational components. c) Younger subjects, compared with older ones, scored significantly higher on Moratorium, Foreclosure and Diffusion, and lower on Achievement. d) Higher educated participants, compared with lower educated ones- scored higher on Achievement and Moratorium and lower on Foreclosure and Diffusion. e) Participants with literature, social and humanitarian backgrounds were significantly higher on Moratorium and Foreclosure identity statuses, compared with participants with sciences and technology backgrounds. No significant differences have been found between the two groups concerning their performance on Achievement and Diffusion.
\end{abstract}


Results of the present study came in line with results of Arab and non -Arab previous studies. The possibility of application of the results in practical fields were discussed and suggestions for further research were provided.

Keywords: identity development, identity statuses, adolescents, adults, Kuwait 


\section{Introduction}

During adolescence, youngsters are faced with challenging task of forming an identity. This process can be either supported or hindered by adolescents' family context (Albert Sznitman, Zimmermann, \& Van Petegem, 2019). There are numerous theoretical approaches that illuminate certain areas of identity development (i.e. Kagen's constructive developmental approach or Blos's object relation approach), but Erik Erikson (1968) psychosocial approach to human development appeals to many professionals because of its utility in many professional areas: clinical, theoretical, and empirical. Erikson's seminal work stressed the importance of history (personal and societal) and social contexts as influencing societies and individuals' lives; consequently, Erikson incorporated these ideas into his concept of identity formation in adolescence.

\subsection{Theoretical Background}

Erikson (1968) assumed that humans pass through a series of stages, each of which is characterized by a developmental conflict. The success or failure of each conflict resolution results in a strengthening or weakening the person's ego, which in turn, leads to a healthy or unhealthy personality, respectively. Based on this theory, Mercia (1966, 1980, 1993) established an Identity Status Paradigm (ISP), which consisted of four statuses: achievement, moratorium, foreclosure, and diffusion. Generally, the description of these identities is significantly based on the explorations of occupational, ideological, political, and sex role domains and the commitments of belief in each domain.

Explorations refer to dynamic deliberations of choices, whereas commitments pertain to the accomplishments of a clear sense of self-definition. Specifically, achievements include people who have passed through a period of active questioning and have established a self-definition. Moratorium includes people who are actively seeking among possibilities to arrive at a given choice. Foreclosure includes people who follow the commitments offered by others (e.g., parents) without exploration. Finally, diffusion includes people who have no specific commitments and are not trying to establish any.

The ISP has dominated psychological research on identity for many years. Psychometrically, a variety of identity tests have been developed such as the Extended Objective Measure of Ego Identity Statuses (EOMES-2) (Bennion \& Adams, 1986), the Identity Style Inventory (Berzonsky, 2001), the Psychosocial Inventory of Ego Strengths (PIES) (Markstrom \& Marshall, 2007), and recently, the Person-Centered Approach "The Six-Process Model of Personal Identity" including the five identity processes described by the dual-cycle model of identity (exploration in breadth, commitment making, exploration in depth, identification with commitment, and ruminative exploration)as well as a sixth identity process of reconsideration of commitment, commonly described in the three-factor model of identity (Albert Sznitman, et al., 2019). Moreover, some studies used the Academic Identity Measure and Global Orientation Questionnaire (Hejazi, et al., 2012), the Utrecht-Management of Identity Commitment Scale (U-MICS: Crocetti, Rubini, \& Meeus 2008) (Arneaud, Alea, \& Eospinety, 2016), and Ego identity Process Questionnaire (Pellerone, Tolini, \& Polopoli, 2016). Ideally, research using the EMOES-2 tests usually identifies participants as having one 
of the four statuses: Achievement, Moratorium, Foreclosure, and Diffusion. For example, Bishop et al. (2005) found that $11.2 \%, 55.8 \%, 16.1 \%$, and $16.9 \%$ of participants were classified as identity achieved, moratorium, foreclosed or diffused, respectively.

\subsection{Psycho-social Characteristics of Identity Statuses}

Examining the psycho-social characteristics of each status has been one of the most important questions in identity research. For example, Toder \& Marcia (1973) found that participants with achievement and foreclosure identities conformed less and felt less uncomfortable than those with moratorium and diffusion identities statuses. However, Adams et al., (1984) found no correlation between all identity statuses and conformity. Rather, they found that diffusion participants were most affected by peer pressures toward conformity, whereas identity -achievement participants were not likely to report engaging in conformity behavior for achievement gains. Slugoski, Marcia, \& Koopman , (1984) found that the identity achievement and moratorium participants characterized with cooperation and facilitation, whereas some foreclosure participants showed antagonistic response patterns; others adopted an acquiescent. For instance, Shanahan \& Pychl (2007) found that diffusion and moratorium statuses correlated positively with procrastination, but achievement status yielded a negative correlation, and foreclosure status showed no significant correlation. Interestingly, the evidence seems to indicate that identity statuses correlated with career development. For example, Blustein, Devenis, \& Kidney (1989) found that occupational commitment was inversely related to the moratorium status, and that career exploration was positively associated with moratorium and identity achieved statuses, and inversely related to the diffusion status.

Identity statuses seem to correlate with psycho-social problems. For example, Bishop et al., (2005) found that identity diffused and foreclosed individuals were relatively heavy consumers of alcohol while moratorium and identity achieved were relatively light consumers of alcohol. Furthermore, Vleioras \& Bosma (2005) concluded that identity styles are important for psychological well-being. At the same vein, Pellerona, et al., (2016) investigated the relationship between identity status, parenting, and adolescent problems (internalized: phobias, obsessions, depression, eating disorders, and entropy; and externalized modes such as alcohol use and school discomfort) in a sample of 198 Italian male and female high school students, who completed sheet of information on the students' alcohol consumption in the past 30 days, and their beliefs about alcohol, the Ego Identity Process Questionnaire, Parental Bonding Instrument, and the Constraints of Mind. Results indicated that (1) Identity status influences alcohol consumption, (2) Low-profile identity and excessive maternal control affect the relational dependence and the tendency to perfectionism in adolescents. Among the predictors of alcohol use, there are socioeconomic status, parental control, and the presence of internalizing symptoms.

The relationships between identity statuses and cognition were also of great interest. For example, Reed, Adams, \& Dobson (1984) found that foreclosure participants were least able to integrate ideas and to think analytically, whereas moratorium and achievement participants were more able to process large amounts of information and to be alone with their thoughts 
and feelings. McLean \& Pratt (2006) found that less sophisticated meaning was associated with the less advanced diffusion and foreclosure statuses, and that more sophisticated meaning was associated with an overall identity maturity index.

\subsection{Cultural and Demographic Variables}

Importantly, however, the influences of context and culture on identity have received relatively little interest, as the original ISP ignored the role of context. Nevertheless, this view has been recently revised, and the role of context has been acknowledged. One hundred years ago, J. Dewey (cited in Walker, 2014) described the attainment of education as a necessary tool for the establishment and sustainability of progress. Education, attending to the good of the public, is designed to instill knowledge in the constituencies it serves. Woods 2004 (cited in Walker, 2014) described the design of education, its services and responsibilities, as an enterprise that promotes ethical, active engagement and respect for everyone. Disconnects between theory and practice exist as education in the United States (and in elsewhere as well) functions to empower some while marginalizing and oppressing others. The above mentioned statements reflect very clearly the important role played by education in human psychosocial development. For example, some researchers found potential effects for micro-and macrocontext on identity. The type of education and socio-economic status (SES) could be good example for micro-context, such that identity statuses significantly differ as function of educational programs and social class. Namely, technology students were found to experience less identity conflicts than students of humanities (Levine, Pakvis, \& Higgins-D'Alessandro, 2000). Also, working class members were more likely to be diffused in occupational identity, whereas upper class participants were more likely to be in moratorium (Solomontos-Kountouri, \& Hurry, 2008). In the same context the study by Gyberg \& Fris'en (2017) found that most of Swedish participants $(N=124)$ were assigned to an achieved global identity and had made identity-defining commitments across domains. Gender differences in identity status were found in the occupational and parenthood domains, and in social comparison but only the parenthood domain, whereas those assigned to moratorium scored higher in social comparison than did those assigned to foreclosure and diffusion. The above mentioned results came in line with results of several previous studies (i.e., the studies by Blustein, et al., 1989; Chrsitina Grove' \& Naude', 2016; Meeus, 1993; ; Solomotos-Kouuntouri \& Hurry, 2008).

Some researchers have tried to investigate the impact of differences by chronological age, adulthood transitions, and values on identity statuses. An example of this kind of research is the study by Arneaud, et al., (2016) which administered the Utrecht-Management of Identity Commitment (U-MICS, Crocetti, Rubini, \& Muees 2008) to 172 Trinidadians, aged between 11 to 84 years old. Results revealed (1) The existence of the following five identity statuses: moratorium, active moratorium, diffusion, evaluative moratorium, and achievement, (2) As expected by the researchers, achievement identity (i.e., commitment and exploration high, reconsideration low) was most common in midlife and among those who had made transitions to marriage and parenthood, (3) Achievement also correlated with higher conservation values (i.e., valuing norm adherence), compared to active moratorium (i.e., commitment low, exploration and reconsideration high), and (4) The moratorium status (i.e., 
commitment and exploration low, reconsideration high) correlated with employment, though age moderated this effect (younger adults who were employed were less likely to be in moratorium).

Some studies sought the relationship between academic identity status, goal orientations and academic achievement. Examples of these studies include the study by Hejazi, et al., (2012) which administered the Achievement Identity Measure and Goal Orientation Questionnaire to 301 of high school students, and associations between academic identity status and goal orientation, and academic achievement. Diffuse academic identity, mastery-approach goal orientation, and foreclosed academic identity explained the greatest amount of variance in academic achievement. Boys, compared with girls, were more likely to have identity diffuse, and mastery-avoidance goal, while girls have higher academic achievement scores, compared with boys. A Russian recent study (Antonova \& Ivanova, 2016) sought gender differences of identity and self-determination process by using a locally devised model of identity statuses based on Marcia's model. Women, compared with men, found to have the identity status "open stable identity", and it was accompanied by more intensive process of self-determination, and men were found to have "closed stable identity", which was associated with the weakening of desire for change that may hinder self-determination process of self-determination and self-development. The main stimulus of self-determination in women was family's welfare, while in men was self-development and achievement of status in society.

\subsection{The Micro-Contextual Influences}

The macro-contextual influences on identity are perhaps more evident. For example, it has been suggested that different societies, or even the same society at different times, lead to different identity developments both quantitatively and qualitatively. Therefore, cross-cultural differences in identity formation could be predicted.

According to the person-in-context theory, which was developed by Adams \& Marshall (1996), the macro- and micro- environmental features combine to influence identity formation. Namely, it has been suggested that macro-level influences are made through different forms of leadership, economic systems, and political and cultural ideologies, whereas micro-level influences are made through a variety of forms of face-to-face social interactions, such as dialogues, conversations and gossip. In addition, Adams \& Marshall (1996) suggested that macro-level influences determine the availability of micro-level effects. Furthermore, Yoder (2000) described some barriers on ISP, which could oppose limitations to ego development, such as the experiences of racism, gender bias, socio-cultural and economic boundaries, and historical change. Crucially, Yoder (2000) assumed that all communities do not necessarily face the same barriers. Rather, a barrier in one community may not exist in another. 


\subsection{Cross-Cultural Comparisons of Identity Statuses}

Unfortunately, however, the cross-cultural studies of identity statuses are relatively rare. Most of the little existed work reported cross-cultural comparisons between United States and a variety of other nations including: Norway, Finland, the Chez Republic, Turkey, and Greece.

One cross-cultural study (Taylor \& Oskay, 1995) found that American adolescents scored higher than Turkish counterparts in identity achievement, moratorium and foreclosure. Another study (Berzonsky, Macek, \& Nurmi, 2003) found that, although participants from United States, Chez Republic and Finland were similar to each other in the social content and identity styles (informational, normative and diffuse/ avoidant), Americans emphasized both personal and collective identity contents more than Finish and Czech participants, who did not differ from each other.

\subsection{The Person-Centered Approach.}

Very recently, some research studies were conducted using other approaches such as person-centered approach in adolescents and youth. Examples of these studies include the studies by Christina Grove' \& Naude' (2016) and Albert Sznitman, et al., (2019). Chtistina Grove' \& Naude' (2016) investigated the relationship between black South African adolescents' identity statuses and their perceived parenting styles by using the Objective Measure of Ego Identity Status and the Parental Authority Questionnaire and found that diffused and achieved identity statuses are related to perceived authoritative and permissive parenting styles, respectively. These results arose a question about the universality of western identity development and parenting styles theories. Albert Sznitman, et al., (2019) sought to value how Swiss adolescents in identity statuses derived from the six-process model differed based on psychological adjustment, perceived family climate, and family communication. Results revealed an identification of the following six identity statuses: Achievement, Foreclosure, Ruminative Moratorium, Reconsidering Achievement, Troubled Diffusion, and Carefree Diffusion. Statuses with the highest degree of commitment showed the most optimal profiles of psychological adjustment and perceived family climate, whereas those with lowest levels of commitment demonstrated the least optimal profiles. Adolescents in the Reconsideration Achievement status, however, reported high levels of both parental support and psychological control. Results showed the effectiveness of the six-process model of identity in the derivation of six identity statuses and in providing further insight into how adolescents in different identity statuses confront identity-related issues in the context of their family. In the same context, Koo ((2018) investigated the influence of achievement motivation and the parent-child relationship on ego identity in Korean nursing students, by using self-report questionnaires to assess ego identity, achievement motivation, the parent-child relationship, and demographic characteristics. Findings revealed a relationship between ego identity and achievement motivation. Achievement motivation of students with moratorium and achieved identity status was significantly higher that of students with low-profile moratorium and diffused identity statuses. Only father-child relationship of students in foreclosure was significantly higher than that of students with diffused identity status. Factors influenced achieved motivation, compared with identity diffused, were 
achievement motivation, year in school, satisfaction with school, and religious beliefs. Results showed that nursing's students; ego identity attainment was more influenced by achievement motivation than by the parent-child relationship. Highly motivated students can develop their own identities regardless of the parent-child relationship.

\subsection{Longitudinal Studies on Identity}

Longitudinal studies on identity formation and development, identity statuses, ego-identity or identity crisis, are very rare. One example of these studies is the study by Fadjukoff, Pulkkinen, \& Kokko (2016) who analyzed the patterns of identity formation in a representative cohort group of Finish men and women born in 1959 across ages 27, 36, 42, and 50, by using Marcia's Identity Status Interview, which include domains: religious beliefs, political identity, occupational career, intimate relationships, and life style. Results showed availability of identity status (diffused, moratorium, foreclosed, and achieved) from all four ages. A great variability was found in identity status across domains at each age level, and the identity trajectories fluctuated from age 27 to 50 . The developmental trend from age 27 to 50 was moderately progressive (toward achievement) for the five domains and for overall identity, with the exception of a slightly regressive trend in male religious identity. Remaining stable in the same status category across the four measurements was rare and emerged only for diffusion in the ideological domains. Women generally outnumbered men in identity achievement at earlier ages, but the gender differences diminished in most domains at age 50, except in religious identity. In women overall diffusion decreased over time, but in men it remained at about $20 \%$ at ages 42 and 50. Very recently, some research studies were conducted using other approaches such as person-centered approach in adolescents and youth.

\subsection{Identity Statuses in Relation with some Psychological and Demographic Variables}

In the West, a huge number of studies on identity have been conducted during the last five decades. These studies have investigated the relationships between identity/ego formation and development and a wide variety of social, psychological and demographic variables and constructs. Examples of these research topics include: Determinants and barriers to ego identity statuses formation (Antonova \& Ivanova, 2016; Berzonsky, 2001; Yoder, 2000; Wires, Barocas, \& Hollenbeck, 1994); role of family and parents' objects and perceived parenting styles in internalizing identity (Adams et al., 1996; Bartle \& Sabatell, 1989; Berzonsky, et al., 2003; Christina Grove' \& Naude', 2016; Koo, 2018; Meeus \& Dekovic, 1995; Pellerona, et al., 2016; Wilson \& Constantine, 1999; Yahav, Eliezer, \& Chen, 2010; O';Connor, 1995); differences and similarities in identity development (Arneaud, et al., 2016; Persoa, Persoa, \& Ping Tam, 1996); identity as an aspect of optimal psychological functioning (Waterman, 1993); identity development and alcohol consumption (Bishop, et al., 2005); identity formation process in relation with career development (Blustein, et al., 1989); identity development and the role of structure of children's games (Baumeister \& Sanders, 1989); gender identity in children (Langer \& Martin, 2004); : personal and social identity in children's self-concept about drawing (Bornhot \& Ingram, 2001); ego identity statuses conformity behavior and personality in late adolescence (Adams et al., 1984; Albert Sznitman, 
et al.,2019; Hejazi, et al., 2012; Lytle, et al., 1997); adults' identity (Fadjukoff, et al., 2016; Gyberg \& Fris'en, 2017; Hamachek, 1985; Levine, et al., 2000); and occupational identity (Meeus, 1993).

\subsection{Research on Identity statuses in Arab World}

A good number of research studies have been conducted on identity status and its correlates, in several Arab countries (such as Egypt, Iraq, Jordan, Saudi Arabia, Algeria, Kuwait, Bahrain, Yemen, and Syria), focused on identity social identity (Zayed, 2003) identity disorders/identity crisis (Abdel-Rahman, 1998b; Al-Tamaway, 2017; Mahmoud, 2011; Morsy, 1997), identity statuses and family context/functioning (Abdel-Moety, 1997a; Morsy, 2002; Alaa el-Din, 2016; Al-Dewash, 2000), coping/ confronting with identity disorder/crisis (Abdel-Rahman, 1998b; Abo-Gazzalla, 2008; Al-Meniazel, 1994; Khalil, 1996; Kashef, 2001; Mohammed, 1991; Morsy, 1997, 2002), measuring ego identity/identity statuses (Abdel-Rahman, 1998a; Abdel-Moety, 1991), socialization/ children's experiences/ parental behavior/ and related academic variables (Abdel-Moety , 1997a, b; Al-Ahwany, 1995; Kateloo, 2009; Kashef, 2001; Mekhemer \& Al-Dufiry, 2003; Mustapha, 2007; Othman, 2005), personality traits and mental/ behavioral disorders (Al-Quatee, 1986; Al-Otaibi, 2005; Eid, 2002; Mohammed, 1991, 1997; Morsy, 1997; Naser, 2010; Torki, 2000), identity statuses/identity formation (Abdel-Moety,1997 a and b, 2000, 2004; Al-Dewash. 2000; Al-Ghamdi, 1994, 2000, 2001; Al-Otaibi, 2005; Al-Qutee, 1986; Booth, 2002; Kateloo, 2009; Mekhemer, \& El-Dhufiry, 2003; Mustapha, 2007), the need of psychological counseling and Logo-therapy (Abo-Gazzalla, 2008; Al-Debaa, 2006; Morsy, 2002), and identity statuses in cross-cultural perspectives; Egypt and Kuwait (Megreya \& Ahmed, 2010). In the followings, some of these studies will be briefly reviewed: Abdel-Moety (1991) found that whereas positive parental treatment correlated with identity achievement, negative parental treatment correlated with identity diffusion in Egyptian university students. Similar results have been reported by Al-Otaibi (2005) in Kuwaiti adolescents and young adults. Finally, a positive correlation between identity achievement and both academic achievement and academic adjustment has been found. Abdel-Moety's (1991) results received support from studies conducted by Mohammed $(1997,2000)$ in Egypt. Third and fourth studies by Abdel-Moety (2000, 2004) reported correlation between psychosocial development (identity) and moral maturity. Results of Abdel-Rahman's study (1998b) on Egyptian youth showed that, whereas identity achievement correlated significantly with dominance, boldness, self-discipline, emotional stability, and conformity, the identity statuses of moratorium, foreclosure, and diffusion correlated with sensitivity, insecurity, tension, and suspiciousness.

Naser (2010) investigated the relationships between moral identity, altruism, egoism, and empathy in samples of male and female students enrolled at Al-Azahar Islamic University in Cairo, Egypt. Samples included also a group of teachers working at religious institutes belong to the same university. Results showed significant positive correlation between levels of moral identity and participants' levels of altruism and empathy, and similar negative correlation between moral identity and egoism. Males significantly outnumbered their female counterparts on moral identity, altruism and egoism, while females scored significantly 
higher on empathy. Teachers scored significantly higher than the students on moral identity, altruism and empathy, and lower on egoism.

In a unique Arab cross-cultural study, Megreya \& Ahmed (2010) compared between Egyptian and Kuwaiti undergraduate university male and female students $(N=433 ; 220$ Egyptians, among them 112 females, with mean of age 18.2 years, SD=09 years; and 213 Kuwaitis, among them 115 females, with mean of age 18.7 years, and $\mathrm{SD}=0.7$ years) by using an Arabic version of the Extended Objective Measure of Ego Identity Statuses-2 (EOMES-2). Results showed that all males were more foreclosed than females, but there was no gender effect/difference on the remaining three statuses (achievement, moratorium, and diffusion). The by-participant and by-item analyses consistently showed that Egyptians were more achieved and less foreclosed and diffused than Kuwaitis. However, identity moratorium was similar between the two nations. Megreya's \& Ahmed's results suggested that identity formation is not purely an internal psychological process. Rather, it is greatly influenced by the macro- and even micro- contexts.

A Jordanian study (Alaa el-Din, 2016) examined ego identity statuses formation process in a sample of college students within the framework of Marcia's Identity Status Paradigm (ISP), and explored the role of depression, self-esteem, and family cohesion and adaptation in the exploration and commitment dimensions of identity statuses. Results showed that self-esteem was the only significant predictor of ego identity exploration, while family cohesion, self-esteem, gender(female) and family adaptation predicted identity's commitment. Females tended to be more classified in achievement and foreclosure identity statuses compared to males who were classified more in moratorium and diffusion. Depression and self-esteem were significant predictors of ego identity and differentiated significantly among the four ego identity status. Lower levels of students report on cohesion and adaptability in their families correlated with moratorium and diffusion identity statuses. Higher levels of students' perceptions of family cohesion and adaptation correlated with achievement and foreclosure identity statuses. A more recent Jordanian study (Al-Azam \& Al-Garah, 2018) sought the predictive ability of ego identity statuses in cultural intelligence in a sample of Jordanian and non Jordanian university students, by using an Arabic version of Adams', Bennion's, \& Huh's Scale of Ego Identity Statuses. Results revealed that achievement identity status was the most prominent predictor of cultural intelligence.

Some Arab researchers have focused on the relationship between psychological counseling and identity crisis. One example of these studies is study by Morsy (2002) who investigated the need for psychological counseling to confront identity crisis among Egyptian adolescent, whereas others have focused on the effectiveness of counseling program based on logo therapy in reducing identity crisis and improving positive meaning of life in university students. Abo-Gazalla's (2008) study in Egypt reported the effectiveness of this kind of counseling program through logo therapy, in reducing identity crisis and in improving the positive meaning of life in a sample of university students. The above mentioned Arab and non Arab studies indicate the need for assessing the identity statuses development/formation among Kuwaitis males and females from different age, educational, academic specialization 
and socioeconomic backgrounds by using the same methodology used by Al-Otaibi, 2005, in Kuwait; and Megreya \& Ahmed, 2010, in Egypt and Kuwait.

\section{Methodology}

\subsection{Aim of the Present Study}

The present study aimed at investigating the identity statuses in Kuwaiti participants from different age groups, and to determine the differences between males and females, between younger and older participants, between lower and higher educated participants, between participants with literature, social, and humanitarian backgrounds and participants with science and technology backgrounds, and from lower and higher academic classes, regarding their performance on the EOMES-2.

\subsection{Hypotheses}

At the hand of the results of several Arab and non Arab previous related studies, the following hypotheses could be set:

2.2.1 The four identity statuses: Achievement, Moratorium, Foreclosure, and Diffusion (and their sub-statuses: Ideological and Relational) could be found among Kuwaitis, as they were found in other societies.

2.2.2 There are significant differences between male and female participants concerning their performance on the four identity statuses scale, where males, compared with their female counterparts, will be found as having significantly more achieved, more moratorium, and more foreclosure. Females, compared with males, will show significantly higher levels of diffusion.

\subsubsection{There are significant differences between younger and older participants} concerning their performance on the measure of the four identity (and their ideological and relational subscales). Older participants will score significantly higher on the scales of Achieved and Moratorium (and their Ideological and Relational subscales), and younger participants will score significantly higher than the older ones, on Foreclosure and Diffusion (and their Ideological and Relational subscales).

\subsubsection{There are significant differences between lower and higher educated participants} concerning their performance on the measure for the four identity statuses. Higher educated participants (university students/graduate, MA and/or Ph.D., holder, compared with lower educated participants (secondary school students/graduates or less), will score significantly higher on the scale of Achievement (and its Ideological and Relational Achievement subscale). Lower educated participants, compared with higher educated ones, will score higher scores on 1. Moratorium (and its two subscales: Ideological and Relational Moratorium), 2. Foreclosure (and its two subscales: Ideological and Relational Foreclosure), and 3. Diffusion. 


\subsection{Sample}

Sample of the present study consisted of 3621 Kuwaiti aged between 12 and 64 years (Mean of age $=22.40$ years, and $\mathrm{SD}=6.21$ years). Sample included 1159 (or 32\%) males (Mean of age $=24.35$ years, and $\mathrm{SD}=7.26$ years), and 2462 (or 68\%) females (Mean of age $=21.82$ years, $\mathrm{SD}=5.55$ years). Sample included 676 (or 18.7\%) of participants aged 24 years or younger; and 2945 (or $81.3 \%$ o) of participants aged between 25 and 64 years. Sample included 477 (or 18.3\%) participants with intermediate and secondary school education; 2049 (or 78.5\%) participants were university students and university graduates; while 85 participants only (or 3.3\%) identified themselves as master students or master and/or Ph. D., holders. As for the academic specialization, 2564 (or 70.8\%) of the participants have described their academic specialization as theoretical, social, and humanitarian, while 1057 (or $29.2 \%$ ) of the participants have identified their academic specialization as science, medicine, pharmacology, and engineering and technology students.

\subsection{Measure}

An Arabic version of the Extended Objective Measure of Ego Statuses-2 (EOMES-2) which was originally devised by Bennion \& Adams (1986) and translated into Arabic by Abdel-Rahman (1998a) in Egypt, was used. This self-report scale consists of 64 items to which participants respond on a 6-point numerical Likert Scale, ranging from 1 "strongly agree" to 6 "strongly disagree". The scale measures the four identity statuses (achievement, moratorium, foreclosure, and diffusion), each of which consisted of 16 items. In addition, each subscale is divided into two smaller subscales. The first of which assesses the ideological aspect, while the second subscale measures the relational aspect. Accordingly, there are eight subscales of the EMOES-2, and they are; 1. ideological achievement, relational achievement, 3. ideological moratorium, 4. relational moratorium, 5. ideological foreclosure, 6. relational foreclosure, 7. ideological diffusion, and 8. relational diffusion. The measure has been used by a large number of studies in Egypt (Abdel-Rahman, 1998b), and it was also used by some graduate students in Kuwait (such as Al-Otaibi, 2005) using 415 of male and female adolescents and which reported the following alpha coefficients: .76 for achievement, .74 for moratorium, .77 for foreclosure, and .88 for diffusion. Those studies have reported very good indicators for the validity and reliability of the measure using a variety of techniques. In Megreya's \& Ahmed's (2010) study, the reliability of the measure was checked by using Cronbach's Alpha and Gutman Split-Half coefficient. Results of analysis showed the followings: For the Egyptian sample, alpha and split-half coefficients were .79 and .82 for achievement, .74 and .84 for moratorium, .82 and .81 for foreclosure, and .74 and .72 for diffusion. As for Kuwaiti sample, alpha and split-half coefficients were: .86 and .85 for achievement, 0.80 and 0.78 for moratorium, 0.88 and 0.87 for foreclosure, and .75 and .80 for diffusion. As for the present study, Cronbach's Alpha coefficients have been calculated. Results show that the measure's four subscales enjoy reasonably high alpha coefficients: .738 for achievement (.506 and .696 for ideological and relational achievement, respectively), .722 for moratorium (.599 and .569 for ideological and relational moratorium, respectively), .870 for foreclosure (.735 and .805 for ideological and 


\section{Ml Macrothink}

relational foreclosure, respectively), and .743 for diffusion (.587 and .657 for ideological and relational diffusion, respectively).

\subsection{Study's Ethical Consent/Ethical Considerations}

The study has followed the standard ethical guidelines for research. Before data collection, the approval of the Institutional Review Board was sought and obtained. All participants signed a consent form and were briefed on the purpose of the study and their rights as participants. The data were kept confidential and the anonymity of participants was upheld throughout the duration of the study and in this article.

\section{Results}

3.1 Comparison between the results of the present study $(N=3621)$ and results of a previous Kuwaiti study (Al-Otaibi, 2005, $N=461$, aged between 15 and 25 years)

Table 1. Comparison between the results of the present study ( $N=3621$, aged between 12-64 years), and Al-Otaibi's (2005) study in Kuwait ( $N=461$, aged between 13-21 years).

\begin{tabular}{|l|c|c|c|c|}
\hline \multirow{2}{*}{ Scales } & $\begin{array}{c}\text { Present Study } \\
(2017 / 2018) . \\
(N=3621 ; \text { ages 12-60 } \\
\text { years })\end{array}$ & \multicolumn{3}{c|}{$\begin{array}{c}\text { Al-Otaibi's Study } \\
(2005)\end{array}$} \\
\hline Age & $M$ & $S D$ & $M$ & $S D$ \\
\hline Ideological Achievement & 22.64 & 6.62 & 17.21 & 3.60 \\
\hline Relational Achievement & 34.70 & 6.18 & --- & --- \\
\hline Achievement & 35.76 & 6.76 & --- & --- \\
\hline Ideological Moratorium & 70.46 & 11.29 & 39.13 & 11.67 \\
\hline Relational Moratorium & 29.94 & 7.08 & -- & --- \\
\hline Moratorium & 31.55 & 6.56 & --- & --- \\
\hline Ideological Foreclosure & 61.49 & 11.86 & 46.22 & 12.45 \\
\hline Relational Foreclosure & 25.49 & 7.95 & --- & --- \\
\hline Foreclosure & 22.83 & 9.00 & --- & --- \\
\hline Ideological Diffusion & 48.31 & 15.87 & 60.38 & 17.45 \\
\hline Relational Diffusion & 26.55 & 6.88 & --- & --- \\
\hline Diffusion & 25.22 & 7.80 & --- & --- \\
\hline
\end{tabular}

Results of the comparison between the results of the present study ( $N=2621$, aged between 12 to 64 years, mean age $=22.64, \mathrm{SD}=6.62$ ), and a previous Kuwaiti study conducted by Al-Otaibi, 2005; $N=461$, mean age $=17.21, \mathrm{SD}=3.60$ ), showed that participants in the present study, were significantly higher on achievement, moratorium, and diffusion, while Al-Otaibi's, 2005 participants were significantly higher on foreclosure than the present study's participants. An explanation for the differences between the two groups, is the age and educational levels differences. 


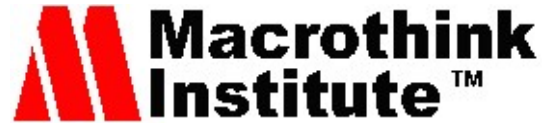

In the following paragraphs differences between males and females, between younger and older participants, lower and higher education participants, and between participants with literature, social sciences, and humanitarian background and participants with sciences and technology backgrounds on four identity statuses: Achievement, Moratorium, Foreclosure and Diffusion, will be presented.

\subsection{Differences between Males and Females}

Sample has been divided - according to gender - into two subgroups: Males $(N=1159$, "or32\%", Mean age=24.00 years, $\mathrm{SD}=7.72$ years), and females $(N=2462$ "or 68\%", Mean age 22.01 years, $\mathrm{SD}=5.94$ years). Table 2 illustrates the results of the comparison between the two sexes.

Table 2. Means and Standard Deviations of the Whole Sample, Males and Females, $t$-values and the Levels of Significance of Differences between Males and Females on the four Identity Statuses

\begin{tabular}{|c|c|c|c|c|c|c|c|c|}
\hline \multirow[t]{2}{*}{ Scales } & \multicolumn{2}{|c|}{$\begin{array}{l}\text { Whole } \\
\text { Sample } \\
N=3621\end{array}$} & \multicolumn{2}{|c|}{$\begin{array}{c}\text { Males } \\
N=1159\end{array}$} & \multicolumn{2}{|c|}{$\begin{array}{l}\text { Females } \\
N=2462\end{array}$} & \multirow[t]{2}{*}{$t$} & \multirow[t]{2}{*}{ Sig. } \\
\hline & $M$ & $S D$ & $M$ & $S D$ & $M$ & $S D$ & & \\
\hline Age & 22.64 & 6.62 & 24.00 & 7.72 & 22.01 & 5.94 & 8.53 & $.000 * *$ \\
\hline $\begin{array}{c}\text { Ideological } \\
\text { Achievement }\end{array}$ & 34.70 & 6.18 & 35.04 & $6-28$ & 34.54 & 6.13 & 2.28 & $.023 *$ \\
\hline $\begin{array}{c}\text { Relational } \\
\text { Achievement }\end{array}$ & 35.76 & 6.76 & 36.55 & 6.73 & 35.39 & 6.75 & 4.86 & $.000 * *$ \\
\hline Achievement & 70.46 & 11.29 & 71.60 & 11.50 & 69.93 & 11.15 & 4.16 & $.000 * *$ \\
\hline $\begin{array}{l}\text { Ideological } \\
\text { Moratorium }\end{array}$ & 29.94 & 7.08 & 29.55 & 7.23 & 30.12 & 7.00 & 2.26 & $.024 *$ \\
\hline $\begin{array}{l}\text { Relational } \\
\text { Moratorium }\end{array}$ & 31.55 & 6.56 & 31.79 & 6.60 & 31.44 & 6.54 & 1.50 & .134 \\
\hline Moratorium & 61.49 & 11.86 & 61.34 & 11.91 & 61.56 & 11.83 & .520 & .603 \\
\hline $\begin{array}{l}\text { Ideological } \\
\text { Foreclosure }\end{array}$ & 25.49 & 7.95 & 26.30 & 8.05 & 25.11 & 7.88 & 4.24 & $.000 * *$ \\
\hline Relational Foreclosure & 22.83 & 9.00 & 23.46 & 9.41 & 22.18 & 8.79 & 2.92 & $.003 *$ \\
\hline Foreclosure & 48.31 & 15.87 & 49.76 & 16.44 & 47.63 & 15.56 & 3.78 & $.000 * *$ \\
\hline Ideological Diffusion & 26.55 & 6.88 & 26.30 & 7.39 & 26.67 & 6.63 & 1.50 & .134 \\
\hline Relational Diffusion & 25.22 & 7.80 & 25.28 & 8.10 & 25.19 & 7.65 & $.31 ` 5$ & .753 \\
\hline Diffusion & 51.77 & 12.69 & 51.58 & 13.61 & 51.86 & 12.24 & .620 & .536 \\
\hline
\end{tabular}

$* * P=<0.01, * P=<0.05$

3.2.1 Achievement: Males outnumbered their female counterparts on the ideological achievement, relational achievement, and also the total score on the subscale: Achievement. In all cases, the differences between the two sexes were significant $(\mathrm{r}=<0.01$ level). 


\section{Macrothink}

3.2.2 Moratorium: While females scored significantly higher than males on the ideological moratorium $(p=<0.05)$, males scored higher, compared with females, on the relational moratorium, and also reported higher total score of the Moratorium. Yet, the differences between the two sexes in this two cases did not reach the limits of significance.

3.2.3 Foreclosure: Males, compared with their female counterparts, scored higher on the foreclosure two subscales: ideological foreclosure, and the relational foreclosure, and also reported higher total score on foreclosure. Differences in all the three cases were significant $(p=<0.01, .05$, and 0.01 levels, respectively).

3.2.4 Diffusion: Females, compared with their male counterparts, scored higher on the diffusion's subscales: ideological diffusion, and also reported a higher total score on the scale: diffusion, males scored slightly higher on the subscale: Relational Diffusion than females did. Yet, the differences between males and females in all the three cases did not reach the limits of significance.

\subsection{Differences between Younger and Older Participants}

Sample has been divided -according to age - into two subgroups: Younger participants ( $N=$ 2945 "or $81.3 \% "$ ", mean age $=20.17, \mathrm{SD}=2.36$ yrs. $)$, and older participants $(N=676$ "or $18.7 \% "$ ", mean age $=33.41, \mathrm{SD}=6.15 \mathrm{yrs}$ ). Table 3 includes the results of the comparison between the two age groups. 
Table 3. Means and Standard Deviation of the Whole Sample, Younger and Older Participants, $t$-values and the Levels of Significance of the Differences between Younger and Older Participants.

\begin{tabular}{|c|c|c|c|c|c|c|c|c|}
\hline \multirow[t]{2}{*}{ Scales } & \multicolumn{2}{|c|}{$\begin{array}{l}\text { Whole } \\
\text { Sample } \\
N=3621\end{array}$} & \multicolumn{2}{|c|}{$\begin{array}{c}\text { Younger Subjects, } \\
24 \text { yrs. And lower } \\
\quad N=2945\end{array}$} & \multicolumn{2}{|c|}{$\begin{array}{c}\text { Older Subjects } \\
N=676 \\
25 \text { yrs. And } \\
\text { older }\end{array}$} & \multirow[t]{2}{*}{$T$} & \multirow[t]{2}{*}{ Sig. } \\
\hline & $M$ & $S D$ & $M$ & $S D$ & $M$ & $S D$ & & \\
\hline Age & 22.64 & 6.62 & 20.17 & 2.36 & 33.41 & 8.26 & 74.72 & $.000 * *$ \\
\hline $\begin{array}{c}\text { Ideological } \\
\text { Achievement }\end{array}$ & 34.70 & 6.18 & 34.70 & 6.19 & 34.70 & 6.15 & & 999 \\
\hline $\begin{array}{c}\text { Relational } \\
\text { Achievement }\end{array}$ & 35.76 & 6.76 & 35.62 & 6.72 & 36.82 & 6.84 & 4.25 & $.000 * *$ \\
\hline Achievement & 70.46 & 11.29 & 70.22 & 11.20 & 71.52 & 11.64 & 2.70 & $.007 *$ \\
\hline $\begin{array}{l}\text { Ideological } \\
\text { Moratorium }\end{array}$ & 29.94 & 7.08 & 30.47 & 6.80 & 27.65 & 7.75 & 9.46 & $.000 * *$ \\
\hline $\begin{array}{l}\text { Relational } \\
\text { Moratorium }\end{array}$ & 31.55 & 6.56 & 31.79 & 6.52 & 30.51 & 6.60 & 4.56 & $.000 * *$ \\
\hline Moratorium & 61.49 & 11.86 & 62.25 & 11.50 & 58.43 & 12.78 & 8.16 & $.000 * *$ \\
\hline $\begin{array}{l}\text { Ideological } \\
\text { Foreclosure }\end{array}$ & 25.49 & 7.95 & 25.75 & 7.93 & 24.33 & 7.95 & 4.20 & $.000 * *$ \\
\hline $\begin{array}{c}\text { Relational } \\
\text { Foreclosure }\end{array}$ & 22.83 & 9.01 & 23.13 & 9.04 & 21.52 & 8.72 & 4.19 & $.000 * *$ \\
\hline Foreclosure & 48.31 & 15.87 & 48.88 & 15.88 & 45.86 & 15.63 & 4.48 & $.000 * *$ \\
\hline $\begin{array}{c}\text { Ideological } \\
\text { Diffusion }\end{array}$ & 26.55 & 6.88 & 26.76 & 6.63 & 25.65 & 7.35 & 3.77 & $.000 * *$ \\
\hline $\begin{array}{l}\text { Relational } \\
\text { Diffusion }\end{array}$ & 25.22 & 7.80 & 25.24 & 7.63 & 25.10 & 8.50 & .437 & .662 \\
\hline Diffusion & 51.77 & 12.69 & 52.01 & 12.44 & 50.74 & 13.73 & 2.32 & $.020 *$ \\
\hline
\end{tabular}

$* * p=<0.01, * p=<0.05$

\subsection{Differences between Younger and Older Participants in identity Statuses}

At the hand of the results included in Table 3, it could be noted the followings: Older participants, compared with younger ones - scored significantly higher on one of the achievement components: Relational achievement (at 0.05 level). Yet, no significant differences have been found between the two age group concerning the Ideological achievement or on the total score on the subscale: Achievement.

Younger participants, compared with their older counterparts, scored significantly higher on the following identity two subscales: Moratorium and Foreclosure (at 0.01, and 0.05 levels, respectively). 
Finally, younger subjects, compared with older ones, scored significantly higher on one of the identity components: Ideological Diffusion (at 0.01 level). Yet, no significant differences have been found between the age groups, concerning the Relational Diffusion or the total score of identity status: Diffusion.

3.5 Differences between Higher Educated Participants and lower Educated Participants have been classified into two subgroups according their level of education: Lower educated participants; secondary school level or lower $(N=477)$, and higher educated participants; university undergraduates or higher "MA and/or Ph.D., holders" (N=2134).

Table 4. Means and Standard Deviation of the Whole Sample, Lower Educated (Intermediate and Secondary Schools Education) and Higher Educated (University Education: B.A., M.A., and Ph.D.) Participants, t-values and the levels of Significance.

\begin{tabular}{|c|c|c|c|c|c|c|c|c|}
\hline \multirow[t]{2}{*}{ Scales } & \multicolumn{2}{|c|}{$\begin{array}{l}\text { Whole } \\
\text { Sample } \\
N=3621\end{array}$} & \multicolumn{2}{|c|}{$\begin{array}{l}\text { Lower Educated } \\
N=822, \text { secondary } \\
\text { school or lower }\end{array}$} & \multicolumn{2}{|c|}{$\begin{array}{c}\text { Higher Educated } \\
\qquad N=2734, \\
\text { under-graduate, } \\
\text { graduate } \\
\text { students, MA or } \\
\text { Ph.D. Holders }\end{array}$} & \multirow[t]{2}{*}{$t$} & \multirow[t]{2}{*}{ Sig. } \\
\hline & $M$ & $S D$ & $M$ & $S D$ & $M$ & $S D$ & & \\
\hline Age & 22.64 & 6.62 & 21.31 & 9.07 & 23.06 & 5.70 & 6.63 & $000 * *$ \\
\hline $\begin{array}{c}\text { Ideological } \\
\text { Achievement }\end{array}$ & 34.70 & 6.18 & 34.50 & 6.73 & 34.70 & 5.78 & .820 & .412 \\
\hline $\begin{array}{c}\text { Relational } \\
\text { Achievement }\end{array}$ & 35.76 & 6.76 & 34.45 & 7.68 & 36.13 & 6.35 & 6.32 & $.000 * *$ \\
\hline Achievement & 70.46 & 11.29 & 68.95 & 12.70 & 70.83 & 10.65 & 4.23 & $.000 * *$ \\
\hline $\begin{array}{l}\text { Ideological } \\
\text { Moratorium }\end{array}$ & 29.94 & 7.08 & 30.12 & 6.78 & 29.82 & 6.96 & 1.090 & .276 \\
\hline $\begin{array}{c}\text { Relational } \\
\text { Moratorium }\end{array}$ & 31.55 & 6.56 & 30.93 & 6.94 & 31.69 & 6.26 & 2.96 & $.003^{*}$ \\
\hline Moratorium & 61.49 & 11.86 & 61.05 & 12.00 & 61.50 & 11.61 & .977 & .328 \\
\hline $\begin{array}{l}\text { Ideological } \\
\text { Foreclosure }\end{array}$ & 25.49 & 7.95 & 26.70 & 7.95 & 25.16 & 7.94 & 4.88 & $.000 * *$ \\
\hline $\begin{array}{c}\text { Relational } \\
\text { Foreclosure }\end{array}$ & 22.83 & 9.00 & 23.92 & 9.12 & 22.50 & 8.80 & 4.02 & $.000 * *$ \\
\hline Foreclosure & 48.31 & 15.87 & 50.62 & 16.00 & 47.66 & 15.69 & 4.72 & $.000 * *$ \\
\hline $\begin{array}{c}\text { Ideological } \\
\text { Diffusion }\end{array}$ & 26.55 & 6.88 & 27.04 & 6.80 & 26.45 & 6.91 & 2.15 & $.032 *$ \\
\hline $\begin{array}{l}\text { Relational } \\
\text { Diffusion }\end{array}$ & 25.22 & 7.80 & 26.42 & 7.59 & 24.82 & 7.52 & 5.36 & $.000 * *$ \\
\hline Diffusion & 51.77 & 12.69 & 53.46 & 12.21 & 51.26 & 12.63 & 4.40 & $.000 * *$ \\
\hline
\end{tabular}

**P $=<0.01, * P=<0.05$ 


\section{Macrothink}

Results illustrated in Table 4 showed the differences between the performance of the two subgroups. Results showed that higher educated participants, compared with lower educated ones, were significantly higher on achievement, and its subscale: Relational achievement $(\mathrm{r}=<0.01)$, and on the subscale: Relational Moratorium $(\mathrm{r}=<0.05)$. Lower educated participants significantly outnumbered their higher educated counterparts on Foreclosure and its two subscales; Ideological and Relational Foreclosure $(\mathrm{r}=<0.01)$, Diffusion and Relational Diffusion $(\mathrm{r}=<0.01)$, and Ideological Diffusion $(\mathrm{r}=<0.05)$.

3.5.1 Achievement: While lower educated participants, compared with higher educated ones, scored significantly higher $(p=<0.05)$ on the ideological achievement, the higher educated participants scored significantly higher $(p=<0.01)$ on the relational achievement. As for the total score on the subscale of achievement, the higher educated participants scored higher than their lower educated counterparts, however, the difference between the two groups did not reach the limits of significant.

3.5.2 Moratorium: Lower educated individuals scored non-significantly higher than higher educated ones on ideological moratorium, but lower on both the relational moratorium (difference was significant at $p=<0.05$ level), and non-significant on the subscale of moratorium.

3.5.3 Foreclosure: Lower educated participants, compared with their higher educated counterparts, scored significantly higher $(p=<0.05)$, on both ideological and relational foreclosure, and also on the subscale of foreclosure.

3.5.4 Diffusion: As in the case of the subscale of foreclosure, lower educated participants, compared with higher educated ones, scored significantly higher on ideological diffusion $(p=<0.05)$, relational diffusion, and on the subscale of diffusion $(p=<0.01)$.

3.6 Differences between Literature, Social Sciences, and Humanities Students and Sciences and Technology Students.

Participants have been classified into two subgroups according to their academic specialization: Literature, Social Sciences, and Humanities $(N=1815)$, and Sciences and Technology students $(N=796)$. 
Table 5. Means and Standard Deviation of the Whole Sample, participants with Literature, Social and Humanities Specialization $(N=2564)$ and participants with Science and Technology Specialization $(N=1057)$.

\begin{tabular}{|c|c|c|c|c|c|c|c|c|}
\hline \multirow[t]{2}{*}{ Scales } & \multicolumn{2}{|c|}{$\begin{array}{l}\text { Whole } \\
\text { Sample } \\
N=3621\end{array}$} & \multicolumn{2}{|c|}{$\begin{array}{c}\text { Literature, Social } \\
\& \text { Humanities } \\
\text { Subjects } \\
N=2564\end{array}$} & \multicolumn{2}{|c|}{$\begin{array}{c}\text { Science \& } \\
\text { Technology } \\
\text { Subjects } \\
N=1057\end{array}$} & \multirow[t]{2}{*}{$T$} & \multirow[t]{2}{*}{ Sig. } \\
\hline & $M$ & $S D$ & $M$ & $S D$ & $M$ & $S D$ & & \\
\hline Age & 22.64 & 6.62 & 21.66 & 5.28 & 25.04 & 8.63 & 14.36 & $.000 * *$ \\
\hline $\begin{array}{c}\text { Ideological } \\
\text { Achievement }\end{array}$ & 34.70 & 6.18 & 34.69 & 6.16 & 34.74 & 6.24 & .225 & .822 \\
\hline $\begin{array}{c}\text { Relational } \\
\text { Achievement }\end{array}$ & 35.76 & 6.76 & 35.68 & 6.79 & 35.95 & 6.70 & 1.07 & .287 \\
\hline Achievement & 70.46 & 11.29 & 70.37 & 11.28 & 70.69 & 11.32 & .761 & .447 \\
\hline $\begin{array}{l}\text { Ideological } \\
\text { Moratorium }\end{array}$ & 29.94 & 7.08 & 30.18 & 7.03 & 29.37 & 7.17 & 3.133 & $.002 *$ \\
\hline $\begin{array}{l}\text { Relational } \\
\text { Moratorium }\end{array}$ & 31.55 & 6.56 & 31.77 & 6.65 & 31.02 & 6.29 & 2.140 & $.002 *$ \\
\hline Moratorium & 61.49 & 11.86 & 61.94 & 11.86 & 60.38 & 11.79 & 3.608 & $.000 * *$ \\
\hline $\begin{array}{l}\text { Ideological } \\
\text { Foreclosure }\end{array}$ & 25.49 & 7.95 & 25.71 & 7.95 & 24.95 & 7.94 & 2.624 & $.009 *$ \\
\hline $\begin{array}{c}\text { Relational } \\
\text { Foreclosure }\end{array}$ & 22.83 & 9.01 & 23.13 & 8.98 & 22.84 & 9.03 & 3.110 & $.002 *$ \\
\hline Foreclosure & 48.31 & 15.87 & 48.84 & 15.89 & 47.05 & 15.79 & 3.079 & $.002 *$ \\
\hline $\begin{array}{c}\text { Ideological } \\
\text { Diffusion } \\
\end{array}$ & 26.55 & 6.88 & 26.78 & 6.82 & 26.01 & 7.00 & 3.049 & $.002 *$ \\
\hline $\begin{array}{l}\text { Relational } \\
\text { Diffusion }\end{array}$ & 25.22 & 7.80 & 25.19 & 7.81 & 25.95 & 7.76 & .286 & .775 \\
\hline Diffusion & 51.77 & 12.69 & 51.96 & 12.72 & 51.28 & 12.62 & 1.476 & .140 \\
\hline
\end{tabular}

** $P=<0.01, * P=<0.05$

Results of the comparison between the two specialization groups showed that while no significant differences have been found between the two specialty groups concerning their performance on the scale of Achievement and its two subscales: Ideological and Relational Achievement. Literature, social and humanities specialization participants, compared with their sciences and technology counterparts, scored significantly higher on Moratorium $(p=<0.01)$, and its two subscales: Ideological and Relational Moratorium $(p=<0.05)$. Similarly, literature, social and humanities group scored significantly higher than sciences and technology group on Diffusion and its two subscales: Ideological and Relational Diffusion. In all the three cases, the difference were significant at 0.05 level. 


\section{$\Lambda$ Macrothink}

3.7 Correlations between the Study's Demographic Variables and the Four Identity Statuses

The matrix of correlations shows the following correlations between study's demographic variables and identity statuses in the whole sample $(N=3621)$.

\subsubsection{Age}

Results showed a significant positive correlation between age and identity status: Achievement, and significant negative correlations between age and each of the following three identity statuses: Moratorium, foreclosure, and diffusion.

\subsubsection{Sex}

Gender (sex) correlated significantly negative with the following two identity statuses: Achievement and Foreclosure (Male participants scored significantly higher than their female counterparts on achievement and foreclosure). No significant correlation has been found between sex and the following two identity statuses: moratorium and diffusion.

\subsubsection{Education}

Participants' educational level correlated significantly positive with identity status: Achievement, and significantly negative with the following three identity statuses: Moratorium, foreclosure, and diffusion. However, these correlations were more strong in the case of females than in the case of males.

\subsubsection{Class (Academic Year)}

Results reveal a significant positive correlation between higher classes (or academic year) and identity status: Achievement, and a significant negative correlation between higher classes (or academic year) and identity status: Moratorium.

\subsubsection{Academic Specialization}

While no significant correlation has been found between academic specialization and the identity status: Achievement, results indicate a significant negative correlation between academic specialization and the following three identity statuses: Moratorium (at .01 level), foreclosure, and diffusion (at .05 level). These correlations mean that participants with literature, social sciences, and humanitarian backgrounds - compared with participants with science and technology backgrounds - were significantly higher on the following three identity statuses: Moratorium, foreclosure, and diffusion.

\subsection{Correlations between the four Identity Statuses}


Table 6. Inter-correlations between Identity Statuses in Kuwaiti Society ( $\mathrm{N}=3621)$.

\begin{tabular}{|c|c|c|c|c|}
\hline $\begin{array}{c}\text { Identity } \\
\text { Statuses }\end{array}$ & Achievement & Moratorium & Foreclosure & Diffusion \\
\hline Achievement & - & $.385^{* *}$ & $.129^{* *}$ & .023 \\
\hline Moratorium & & & $.400^{* *}$ & $.470^{* *}$ \\
\hline Foreclosure & & & & $.608^{* *}$ \\
\hline Diffusion & & & & - \\
\hline
\end{tabular}

$* * P=<0.01$.

Correlation matrix in Table 6 reveals significant positive inter-correlations (at $p=<0.01$ level) between the four identity statuses except the correlation between achievement and diffusion.

\section{Summary}

To sum up, in general, results of the present study proved the suitability of using Bennion's and Adams' Extended Objective Measure of Ego Statuses-2 (EOMES-2) as a measure for determining the for identity statuses: Achievement, foreclosure, moratorium and diffusion in an Arabic milieu, such as Kuwait. These results came in agreement with results of several Arab and non Arab previous studies among them al-Otaibi, 2005; Megreya \& Ahmed, 2010, and Bishop, et al., 2005. As for the impact of gender, age, education and academic specialization, results of the present study showed that male participants, compared with female ones, were significantly higher on achievement and foreclosure. Older participants, compared with younger ones, were significantly higher on achievement, and lower on moratorium, foreclosure and diffusion. Higher educated participants were higher on achievement and moratorium and lower on foreclosure and diffusion, compared with lower educated participants. Finally, participants with literature, social and humanitarian background were significantly higher on moratorium and foreclosure, compared with participants with science and technology backgrounds. Results of the present study indicated the important role of gender, age, and the educational level and academic specialization in identity formation and development. These results came in agreement with results of a huge number of Arab and non arab previous studies (examples include the studies by Abdel-Rahman, 1998b; Al-Otaibi, 2005; Megreya \& Ahmed, 2010; Naser, 2010; Alaa el-Din, 2016; Adams, et al., 1996; Albert Sznitman, et al., 2019; Antonova \& Ivanova, 2016; Arneaud, et al., 2016; Bartle \& Sabateli, 1989; Fadjukoff et al., 2016; McKinney, 2001; Patterson, et al., 1993; Pellerona, et al., 2016; Skoe, et al., 2004; Schwartz \& Montegomery, 2002; Vleiolas \& Bosma, 2005).

\section{Conclusion}

Although the use of the four statuses model suggested by Marcia, 1980, some very recent studies (Albert Siznitman, et al., 2019) showed the effectiveness of using the emerging six-process model of identity statuses (Achievement, Foreclosure, Ruminative Moratorium, Reconsidering Achievement, Troubled Diffusion, and Carefree Diffusion) which provide further insight into how adolescents in different identity statuses confront identity-related issues in the context of their family. In the same context, some studies (i.e., Christina Grove' 
and Naude', 2016, in South Africa) had brought into question the universality of Western identity development and parenting styles theories.

In his chapter, Walker (2014), through critical lens, juxtaposed ideals of equality and equity to discuss how integrating critically and identity development into educational praxis will assist in creating inclusive, equitable practice prepared to meet the needs of learners from low socioeconomic backgrounds. Walker's statement reflects the importance role played by education in identity development.

Results of several studies (i.e., Abdel-Moety, 1997a; Alaa el-Din, 2016; Bartle \& Sabatelli, 1989; Meeus \& Dekovic, 1995; Perosa, et al., 1996) suggested that family processes may play a greater role than psychological wellbeing in determining ego identity formation in late adolescence and emerging adulthood years, and this may be related to the fact that wellbeing may arise in part from associated differences in family processes. Results of Megreya \& Ahmed (2010) suggested that identity formation is not purely an internal psychological process, it is greatly influenced by the macro- and micro-contexts. However, some studies ((Koo, 2018) suggest that students' ego identity attainment was more influenced by achievement motivation than by the parent-child relationship, which indicate that highly motivated students can develop their own identities regardless of the parent-child relationship. Some other studies (i.e., Arneaud, et al., 2016) showed the importance of considering chronological age, culturally meaningful markers (marriage) of transitioning to adulthood, and the relations between values, well-being, and national levels of human development (identity development).

The results of the present study and the results of a huge number of previous Arab and non Arab related studies (examples include the studies by: Abdel-Moety, 1997a; Abo Gazzalla, 2008; Alaa el-Din, 2016; Al-Debaa, 2006; Kashef, 2001; Khalil, 1996; Morsy, 2002; Albert Siznitman, et al. 2019; Bartle \& Sabatelli, 1989: Hamachek, 1985; Koo, 2018; Meeus \& Dekovic', 1995; Peelerona, et al., 2016; O'Connor, 1995; Samuolis, Layburn, \& Schinaffiano, 2001: Wilson \& Constantine, 1999; Zucker, 32002; Zucker, et al., 2001) recommend the need to conduct further studies and that counseling interventions should be target family functioning, and the practices of parents to direct them to the ways of furthering support the process of psychological and social development of their children.

\section{Suggestions for Further Research}

In sum, further research studies on identity development, especially in the Arab world, are very much needed. This research should include the investigation of the roles/impacts of the family (especially children's perception of parental acceptance-rejection. An earlier Kuwaiti study by Al-Otaibi, 2005, revealed strong positive correlations between children's perception of their parental acceptance and identity statuses such as achievement status) and school and other demographic variables, (i.e. gender, age, educational level and academic specialization, and perhaps variables such as parents' educational and vocational levels, family SES, family size and birth order, etc.) in children's formation and development of identity statuses in adolescents and barriers which could hindered this development. Suggested research should 


\section{MlMacrothink}

Journal of Studies in Education

ISSN 2162-6952

2021, Vol. 11, No. 1

also include investigating the effectiveness of counseling/training programs (based on results of the present study and results of previous Arab and non Arab studies).

\section{Study's Limitations}

The study has of course, limitations. First, the group of the participants $(N=3621)$ was a convenience real sample), but it was mainly restricted to Kuwait University's and the Public Authority for Applied Education and Training's students. Generalizations must, however be made with care. Second: age may play a role, that is, the development of identity statuses such as achievement in older people, may differ from those of the young people. It could be important to repeat the study using adolescents, young and old adults as well. In this context, longitudinal studies on the identity development strongly recommended. Third: the participants responded to one self-report questionnaire, not to real situations. The use of these self-report questionnaires, however, is useful. Such questionnaires and scales permitted statistical analyses to reveal how people weigh and combine separate factors - and have been validated. The self-report questionnaires and scales have been repeatedly criticized, due to the great impact and influence of sociability on them, it should be noted that the results the present study are based on self-report questionnaires from college students and adult participants. Consequently, it would be constructive for future research to investigate the identity statuses and their relation to perceptions of parental acceptance-rejection and psychological adjustment on actual acts in applied settings. In our opinion, using real situations based measures (examples include the studies by Ahmed, Azar, \& Mullet, 2007; Vera Cruz \& Mullet, 2019) may will be better in revealing the real identity development. Also, congruent with previous research, other constructs not included in the present study (e.g., insecurity, happiness, self-compassion, empathy, altruism, emotional and spiritual intelligence, etc.) may shed some light on the development of identity and warrant empirical attention. Fourth limitation is relating to measure of identity statuses. This measure was translated into Arabic by Abdel-Rahaman (1998a) for use in assessing identity statuses in the Arab milieu. Although the measure exhibited (statistically) satisfactory level of reliability and their expletory factor analysis yielded acceptable construct validity, the measure needs to be validated for convergent and discrimination in future research. Fifth: Although the results of the present study are clear-cut and came in line with results of several previous studies, using an extra measure for assessing identity statuses as a criteria for the Extended Objective Measure of Ego Statuses-2 (EOMES-2), is highly recommended. Sixth, results of the present study showed that females significantly outnumber their male counterparts on forgiveness, but they were significantly lower than males on vengeance. These results raised the following question: whether age would have had a greater or lesser effect for females than males. Sixth limitation has to do with the generalizability of the obtained results that could only be inductive of the development of identity statuses in Kuwait. To portray a representative picture of the development of identity statuses in their relation with other psychological constructs such as perception of parental acceptance-rejection or psychological adjustment in the Arab world, future research would need a large representative sample recruited from various Arab countries. Finally, seventh limitation has to do with more hope in further research: Large number of population across the ages could have been included to better 
understanding of the development of identity statuses and their relationship with other psychological constructs. More independent variables could have been identified and included to increase the scientific vigor of the study. Qualitative method could have been identified and included to increase the scientific vigor of the study. Qualitative method could have been included for in-depth exploration.

\section{Declaration of Conflicting Interests}

The authors declared no potential conflicts of interests with respect to the research, authorship, and/or publication of this article.

\section{Ethical Approval}

The authors assert that all procedures contributing to this work comply with the ethical standards of the relevant national and institutional committees on human experimentation and with the Helsinki Declaration of 1975, as revised

\section{Funding}

The authors received no financial support for research, authorship, and/or publication of this article.

\section{Acknowledgments}

We are thankful of students in the Faculties of Social Sciences and Education, Kuwait University and the College of Basic Education, Kuwait, and other participants who participated in the study with much enthusiasm. We also acknowledge the authors whose research findings helped us accomplish our study.

\section{References}

Abdel-Moety, H. M. (1991). Measuring ego identity: Criterion for assessing identity statuses according Marcia Interview. Om Durman (Sudan): Dar Om Durman University for Printing and Publishing (in Arabic).

Abdel-Moety, H. M. (1997a). Family socialization and its impact on identity formation among university students. Journal of the Faculty of Education, Zagazig University (Egypt), 14, 233-278 (in Arabic).

Abdel-Moety, H. M. (1997b). A study of some academic variables in relation to identity formation among university students. Journal of Psychology (Egypt), 7(25), 6-36 (in Arabic).

Abdel-Moety, H. M. (2000). Theory of identity formation in J. Mercia. In H. m. Abdel-Moety (Ed.), Developmental psychology (pp. 298-332), Cairo, Egypt: Dar el-Shorouk (in Arabic).

Abdel-Moety, H. M. (2004). Psychological and social development and identity formation. Cairo, Egypt: Dar el-Shourouk (in Arabic).

Abdel-Rahman, M. E. (1998a). An Objective Measure for Ideological and Social Identity Statuses in stages of adolescence and early adulthood. Cairo: Dar Qabaa (in Arabic). 
Abdel-Rahman, M. E. (1998b). Personality characteristics in relation to styles of coping with identity crisis among secondary school and university students. In M. E. Abdel-Rahman (Ed.), Studies in mental health: Social skills, psychological independence, and identity, 2, 389-470, Cairo: Dar Qabaa (in Arabic).

Abo-Gazzalla, S. A. (2008). The effectiveness of a suggested counseling program based on logo therapy in reducing identity crisis and in improving the positive meaning of life among university students. Proceedings of the $14^{\text {th }}$ Annual Conference of the Center of Counseling (pp. 157-202), Ain Shams University, Cairo, Egypt (in Arabic).

Adams, G. R. \& Marshall, S. K. (1996). A developmental social psychology of identity: Understanding the person-in context. Journal of Adolescence, 19, 429-442. https://doi.org/10.1006/jado.1996.0041

Adams, G. R., Ryan, J. H., Hoffman, J. J., Dobson, W. R., \& Nielson, E. C. (1984). Ego identity status, conformity behavior, and personality in late adolescence. Journal of $\begin{array}{llll}\text { Personality Social and Pychology, } & 47, & 10991-1104 .\end{array}$ https://doi.org/10.1037/0022-3514.47.5.1091

Ahmed, R. A., Azar, F.\& Mullet, E. (2007). Interpersonal forgiveness among Kuwaiti adolescents and adults. Conflict Management and Peace Science, 24, 1-12. https://doi.org/10.1080/07388940701468385

Alaa el-Din, G. M. (2016). Ego identity statuses among university students: The role of well-being and family functioning. Dirasat: Educational Sciences (Jordan), 43(1), 103-134 (in Arabic). https://doi.org/10.12816/0029990

Al-Ahwany, H. H. (1995). Some variables related to identity among Egyptian youth. Unpublished doctoral dissertation, Al-Azhar University, Cairo, Egypt (in Arabic).

Al-Azam, E. F. H. \& Al-Garah, A. Z. (2018). The predictive ability of ego identity statuses in cultural intelligence among Jordanian and non-Jordanian students at Yarmouk University. IUG Journal of Educational \& Psychological Studies (Jordan), 26(5), 367-398 (in Arabic).

Albert Sznitman, G., Zimmermann, G., \& Van Petegem, S. (2019). Further insight into adolescent, personal identity statuses: Differences based on self-esteem, family climate, and family communication. Journal of Adolescence. 71, 99-109. Date of Electronic Publication: 2019 Jan 21. https://doi.org/10.1016/j.adolescence.2019.01.003

Al-Debaa, F. A. (2006). The effectiveness of Logo-Therapy in reducing identity crisis and achieving a positive life meaning among visually disabled adolescents. Unpublished doctoral dissertation, South Valley University, Egypt (in Arabic).

Al-Dewash, F. M. (2000). Identity statuses in adolescent and their relation to parental and school authorities. Unpublished master thesis, Cairo University, Egypt (in Arabic).

Al-Ghamdi, H. A. (1994). The relationship between moral reasoning and ego development in college men and women in Saudi Arabia. Unpublished doctoral dissertation, University of Pittsburg, USA. 
Al-Ghamdi, H. A. (2000). Ego-identity formation in samples of juvenile delinquents and non delinquents in western region in the Kingdom of Saudi Arabia. Arab Journal for Security and Training Studies, Naief Academy for Security Sciences (Saudi Arabia), 5(30), 182-213 (in Arabic).

Al-Ghamdi, H. A.(2001). The relationship between ego-identity formation and the development of moral thinking in a sample of adolescent and youth males in the western region of the Kingdom of Saudi Arabia. Egyptian Journal of Psychological Studies (Egypt), 8(29), 221-255 (in Arabic).

Al-Meniazel, A. F. (1994). Identity crisis: A comparative study between juvenile delinquents and non delinquents. Studies (Jordan), 21(1), 137-171 (in Arabic).

Al-Quatee, A. (1986). The relationship of dogmatism, moral-, ego-development and sex role among college students in different fields in Saudi Arabia. Unpublished doctoral dissertation, University of Pittsburg, USA

Al- Otaibi, D. R. (2005). The relationship between identity disorders, perception of parental acceptancel rejection, ego strength, and single mindedness in samples of intermediate and secondary schools students in Kuwait. Unpublished master thesis, Kuwait University, Kuwait (in Arabic).

Al-Tamaway, E.I. (2017). Variations (differences) in identity disorder, emotional stability by variations (differences) in parental treatment. Journal of Research in Education, University of Mosel (Iraq), 18, 547-558 (in Arabic).

Arneaud, M. J., Alea, N., \& Eospinety, M. (2016). Identity development in Trinidad: Status differences by age, adulthood transitions and culture. Identity, 16(1), 59-71. https://doi.org/10.1080/15283488.2015.1121818

Antonova, N. V. \& Ivanova, N. L. (2016). Gender differences in identity features and self determination process. IAFOR Journal of Psychology \& Behavioral Sciences, 2(2), 47-64. https://doi.org/10.22492/ijpbs.2.2.04

Bartle, S. E., \& Sabatelli, R. M. (1989). Family system dynamics, identity development, and adolescent alcohol use: Implications for family treatment. Family Relations, 38, 258-265. https://doi.org/10.2307/585050

Baumeister, R. F., \& Senders, P. S. (1989). Identity development and the role structure of children's games. The Journal of Genetic Psychology, 150(1), 19-37. https://doi.org/10.1080/00221325.1989.9914571

Bennion, L. \& Adams, G. R. (1986). A revision of the extended version of the objective measure of ego identity status: An identity instrument for use with late adolescents. Journal of Adolescence Research, 1, 183-198. https://doi.org/10.1177/074355488612005

Berzonsky, M. D. (2001). Eriksonian developmental stages. In W. E. Carighead \& C. B. Nembroff (Eds.), The Corsini encyclopedia of psychology and behavioral sciences. $3^{\text {rd }}$ ed. 2 , 513-514, New York: John Wiley \& Sons. https://doi.org/10.1177/0743558402250344 
Berzonsky, M. D., Macek, P., \& Nurmi, J. E. (2003). Interrelationships among identity process, content, and structure: A cross-cultural investigation. Journal of Adolescent Research, 18, 112-130.

Bishop, D. L., Weisgram, E. S., Holleque, K. M., Lund, K. E., \& Wheeler-Anderson, J. R. (2005). Identity development and alcohol consumption: Current and retrospective self-reports by college students. Journal of Adolescence, 37, 160-168. https://doi.org/10.1016/j.adolescence.2004.10.007

Blustein, D. L., Devenis, L. E., \& Kidney, B. A. (1989). Relationship between the identity formation process and career development. Journal of Counseling Psychology, 36, 196-202. https://doi.org/10.1037/0022-0167.36.2.196

Bornhot, L. J., \& Ingram, A. (2001). Personal and social identity in children's self-concepts about drawing. Educational Psychology, 21(2), 151-166. https://doi.org/10.1080/01443410020043850

Booth, M. (2002). Arab adolescents facing the future: Enduring ideals and pressures to change. In B. B. Brown, R. W. Larsen, \& T. S. Saraswathi (Eds.,), The world's youth: Adolescents in eight regions of the globe (pp. 207-242). Cambridge, UK: Cambridge University Press. https://doi.org/10.1017/CBO9780511613814.008

Christina Grove', L. \& Naude', L. (2016). Identity status and perceived parenting style in adolescents living in central South Africa. Journal of Psychology in Africa, 26(2),189-193. https://doi.org/10.1080/14330237.2016.1172811

Eid, M. I. (2002). Identity, anxiety, and creativity. Cairo: Dar al-Qahera (in Arabic).

Erikson, E. H. (1968). Identity: Youth and crisis. New York: Norton.

Fadjukoff, P., Pulkkinen, L., \& Kokko, J K.(2016). Identity formation in adulthood: A longitudinal study from age 27 to 50 . Identity, 16(1), 8-23. https://doi.org/10.1080/15283488.2015.1121820

Gyberg, F. \& Fris'en, A. (2017). Identity status, gender, and social comparison among young adults. Identity, 17(4), 239-252. https://doi.org/10.1080/15283488.2017.1379905

Hamachek, D. E. (1985). The self's development and ego growth: Conceptual analysis and implications for counselors. Journal of Counseling and Development, 64, 136-142. https://doi.org/10.1002/j.1556-6676.1985.tb01053.x

Hejazi, E., Lavasani, M. G., Amani, H., \& Was, C. A. (2012). Academic identity status, goal orientation, and academic achievement among high school students. Journal of Research in Education, 22(1), 291-320.

Khalil, N. S. (1996). Styles of coping with identity crisis and its relation to psychological independence from parents in the late adolescence stage: An empirical and clinical study. Journal of the Faculty of Education, Zagazig University (Egypt), 27(Part 1), 163-224 (in Arabic). 
Kashef, A. F. (2001). Value system among university female students and its relation to their styles (methods) in confronting identity crisis. Psychological Studies (Egypt), 11(3), 465-528 (in Arabic).

Kateloo, K. H. (2009). The relationship between the development of psychological identity and academic adjustment in university students Journal of Psychology (Egypt), 22(80/81), 62-87 (in Arabic).

Koo, H. Y. (2018). Influence of achievement motivation and parent-child relationship on ego identity in Korean nursing students. Child Health Nursing Research, 24(1), 48-57. https://doi.org/10.4094/chnr.2018.24.1.48

Langer, S. J., \& Martin, J. I. (2004). How dresses can make you mentally ill: Examining gender identity disorder in children. Child and Adolescent Social Work Journal, 21(1), 5-23. https://doi.org/10.1023/B:CASW.0000012346.80025.f7

Levine, C. G., Pakvis, P., \& Higgins-D'Alessandro, A. (2000). Ego and moral development in university contexts: The value consistency thesis extended. Journal of Adolescent Research, 15, 482-503. https://doi.org/10.1177/0743558400154004

Lytle, L. J., Bakken, L., \& Romig, C. (1997). Adolescent female identity development. Sex Roles. 37(3/4), 175-185. https://doi.org/10.1023/A:1025643710311

Marcia, J. E. (1966). Developmental validation of ego -identity status. Journal of Personality and Social Psychology, 3, 551-558. https://doi.org/10.1037/h0023281

Marcia, J. E. (1980). Identity in adolescence. In J. Adelson (Ed.), Handbook of adolescent psychology (pp. 149-173), New York: Wiley.

Marcia, J. E. (1993). The ego identity status approach to ego identity. In J. E. Marcia, A. S. Waterman, D. R. Matteson, S. L. Archer, \& J. L. Orlofsky (Eds.), Ego identity: A handbook for psychosocial research (pp. 3-21), New York: Springer-Verlag. https://doi.org/10.1007/978-1-4613-8330-7_1

Mahmoud, A. M. (2011). Identity crisis among intermediate school students. Journal of Educational Psychological Research, Mosel University (Iraq), 31, (in Arabic).

Markstrom, C. A. \& Marshall, S. K. (2007). The psychosocial inventory of ego strengths: examination of theory and psychometric properties. Journal of Adolescence, 30, 63-79. https://doi.org/10.1016/j.adolescence.2005.11.003

McKinney, K. (2001). Identity formation. In W. Edward Craighead and C. B. Nemberoff (Eds.), The Corsini encyclopedia of psychology and behavioral sciences. $3^{\text {rd }}$ ed. (Vol. 2, 723-724), New York: John Wiley \& Sons.

McLeen, K. C. \& Pratt, M. W. (2006). Life's little (and big) lessons: Identity statuses and meaning-making in the turning point narratives of emerging adults. Developmental Psychology, 42, 714-722. https://doi.org/10.1037/0012-1649.42.4.714 
Meeus, W. (1993). Occupational identity development, school performance, and social support in adolescence: Findings of a Dutch study. Adolescence, 28(112), 809-818.

Meeus, W., \& Dekovic', M. (1995). Identity development, parental and peer support in adolescence: Results of a national Dutch survey. Adolescence, 30(120), 931-944.

Megreya, A. M., \& Ahmed, R. A. (2010). A cross-cultural investigation of identity statuses in Middle Eastern countries. The Journal of North African Studies, 16(1), 65-73. https://doi.org/10.1080/13629387.2010.496231

Mekhemer, E. M., \& El-Dhufiry, A. B. (2003). Childhood abusive experiences and gender identity disorder. Psychological Studies (Egypt), 13(3), 447-486 (in Arabic).

Mohammed, M. A. (1991). A comparative study on self-esteem among university students in the light of the differences in students and their coping/confronting styles to identity crisis. Journal of the Faculty of Education, Zagazig University (Egypt), 6(14), 1-39 (in Arabic).

Mohammed, A. M. (1997). Identity crisis and depression among university students. Psychological Studies (Egypt), 7(3), 323-352 (in Arabic).

Mohammed, A. M. (2000). Styles of coping with identity crisis among university youth. In A. M. Mohammed (Ed.,), Styles of coping with identity crisis among university youth. (pp. 1191), Cairo: Dar el-Rashad (in Arabic).

Morsy, A. M. (1997). Identity crisis and depression among university students. Psychological Studies (Egypt), 7(3), 323-352 (in Arabic).

Morsy, A. M. (2002). Identity crisis in adolescence and the need foe psychological counseling. Cairo: Mektabet el-Nahada al-Mesria (in Arabic).

Mustapha, M. A. (2007). Some styles of parental treatment and their relation to ego identity among university students. Proceedings of the $1^{\text {st }}$ Regional Conference on Psychology, Egyptian Psychologists Association (pp. 223-290), Cairo, Egypt, November 18-20, 2007 (in Arabic).

Naser, A. G. (2010). Altruism, egoism, empathy, and moral identity among male and female students, Al-Azhar University. Proceedings of the $15^{\text {th }}$ Annual Conference of Counseling Center "Counseling and Community Development: Toward A Wide Horizons of Counseling", (Vol.1, pp. 171-220), Ain Shams University, Cairo, Egypt, October 3-4, 2010 (in Arabic).

Patterson, S. J., Sochting, I. \& Marcia, J. E. (1993). The inner space and beyond: Women and identity. In G. R. Adams, T. P. Gullotta, \& R.

Montemayor (Eds.), Adolescent identity formation. Vol.4, Advances in adolescent development (pp. 9-24), Newbury Park, CA: Sage (McKinney, 2001).

Pellerona, M., Tolini, G., \& Polopoli, C. (2016). Parenting, identity development, internalizing symptoms, and alcohol use: A cross-sectional study in a group of Italians adolescents. Neuropsychiatric Disease and Treatment, 2016(1), 1769-1778. https://doi.org/10.2147/NDT.S106791 
Perosa, L. M., Perosa, S. L., \& Ping Tam, H. (1996). The contribution of family structure and differentiation to identity development in females, 43, 901-911. https://doi.org/10.1007/BF01537456

O'Connor, B. P. (1995). Identity development and perceived parental behavior as sources of adolescent egocentrism. Journal of Youth and Adolescence, 24(2), 205-227. https://doi.org/10.1007/BF01537150

Othman, I. Y. (2005). Sexual identity disorder and its relation to some family and demographic variables among students of first phase of basic education: A psychometric and clinical study. Unpublished master's thesis, South Valley University, Egypt (in Arabic).

Reed, D., Adams, G. R., \& Dobson, W. R. (1984). Ego identity status, personality, and social influence style. Journal of Personality and Social Psychology, 46, 169-177. https://doi.org/10.1037/0022-3514.46.1.169

Samuolis, J., Layburn, K., \& Schiaffino, K. M. (2001). Identity development and attachment to parents in college students. Journal of Youth and Adolescence, 30(3), 373-384. https://doi.org/10.1023/A:1010448313516

Schwartz, S. J., \& Montgomery, M. J. (2002). Similarities or differences in identity development? The impact of acculturation and gender on identity process and outcome. Journal of Youth and Adolescence, 31(5), 359-372. https://doi.org/10.1023/A:1015628608553

Shanahan, M. J. \& Pychl, T. A. (2007). An ego identity perspective on volitional action: Identity status, agency, and procrastination. Personality and Individual Differences, 43, 901-911. https://doi.org/10.1016/j.paid.2007.02.013

Skoe, E. E., Cumberland, A, Eisenberg, N, Hansen, K., \& Perry, J. (2004). The influences of sex and gender-role identity on moral cognition and pro-social personality traits. Sex Roles, 46(9/10), 295- 309. https://doi.org/10.1023/A:1020224512888

Slugoski, B. R., Marcia, J. E., \& Koopman, R. F. (1984). Cognitive and social interactional characteristics of ego identity statuses in college males. Journal of Personality and Social Psychology, 47, 646-661. https://doi.org/10.1037/0022-3514.47.3.646

Solomontos-Kountouri, O. \& Hurry, J. (2008). Political, religious and occupational identities in context: Placing identity status paradigm in context. Journal of Adolescence, 31, 241-258. https://doi.org/10.1016/j.adolescence.2007.11.006

Taylor, R. D. \& Oskay, G. (1995). Identity formation in Turkish and American late adolescents. Journal of Cross-Cultural Psychology, 26, 8-22. https://doi.org/10.1177/0022022195261002

Toder, N. L.\& Marcia, J. E. (1973). Ego identity status and response to conformity pressure in college women. Journal of Personality and Social Psychology, 26, 287-294. https://doi.org/10.1037/h0034477 


\section{Macrothink}

Torki, M. A. (2000). Ego strength and stress reaction in Kuwaiti students after the Iraqi invasion. Psychological Reports, 87, 188-192. https://doi.org/10.2466/pr0.2000.87.1.188

Vera Cruz, G., \& Mullet, E. (2019). Empathy and forgiveness among Mozambican wives. International Perspectives in Psychology: Research, Practice, and Consultation, 8(3), 124-143. https://doi.org/10.1037/ipp0000110

Vleiolas, G. \& Bosma, H. A. (2005). Are identity styles important for psychological well-being?. Journal of Adolescence, 28, 397-409. https://doi.org/10.1016/j.adolescence.2004.09.001

Walker, A. (2014). Identity status, and culture: Examining barriers of success for students from low socioeconomic backgrounds. New Directions for Teaching and Learning, 140, 23-30. https://doi.org/10.1002/t1.20110

Waterman, A. S. (1993). Identity as an aspect of optimal psychological functioning. In G. R. Adams, T. P. Gullota, \& R. Montemayor (Eds.), Adolescent identity functioning, 4, Advances in adolescent development (pp. 50-72), Newbury Park, CA: Sage .

Wilson, J. W., \& Constantine, M. G. (1999). Racial identity attitudes, self-concept, and perceived family cohesion in black college students. Journal of Black Studies, 29(3), 354-366. https://doi.org/10.1177/002193479902900302

Wires, J. W., Barocas, R., \& Hollenbeck, A. E. (1994). Determinants of adolescent identity development: A cross-sequential study of boarding school boys. Adolescence, 29(114), 361-377.

Yahav, R., Eliezer, K., \& Chen, K. O. (2010). The "father" object as internalized by young male adults, and its relation to separation-individuation patterns, identity status, autonomy, anxiety, and depression. Paper presented at the $3^{\text {rd }}$ International Congress on Interpersonal Acceptance and Rejection, University of Padua, Padua, Italy, July 28-31, 2010.

Yoder, A. E. (2000). Barriers to ego identity status formation: An contextual qualification on Marcia's identity status paradigm. Journal of Adolescence, 23, 95-106. https://doi.org/10.1006/jado.1999.0298

Zayed, A. M. (2003). Psychological components of social identity: A comparative study of Egyptian groups. Unpublished doctoral dissertation, South Valley University, Egypt (in Arabic).

Zucker, K. J. (2002). A factual correction to Bartlett, Vasey, and Bukowski's (2000). Is gender identity disorder in children a mental disorder?. Sex Roles, 46(7/8), 263-264. https://doi.org/10.1023/A:1019923500108

Zucker, K. J., Beaulieu, N., Bradley, S. J., Grimshaw, G. M., \& Wilcox, A. (2001). Handedness in boys with gender identity disorder. Journal of Child Psychology, 6(2), 767-776. https://doi.org/10.1111/1469-7610.00773 